\title{
Green@Universiti Putra Malaysia: cultivating the green campus culture
}

\author{
Ahmad Zaharin Aris ${ }^{1,}$, Zakiah Ponrahono ${ }^{1}$, Mohd Yusoff Ishak ${ }^{1}$, Nor Hazlina Zamaruddin ${ }^{2}$, Nor Kamariah Noordin ${ }^{2}$, \\ Renuganth Varatharajoo ${ }^{3}$, and Aini Ideris $^{4}$ \\ ${ }^{1}$ Faculty of Environmental Studies, Universiti Putra Malaysia, 43400 UPM Serdang, Selangor, Malaysia \\ ${ }^{2}$ Corporate Strategy and Communications Office, Universiti Putra Malaysia, 43400 UPM Serdang, Selangor, Malaysia \\ ${ }^{3}$ Office of the Deputy Vice Chancellor (Industry and Community Relations), Universiti Putra Malaysia, 43400 UPM Serdang, Selangor, \\ Malaysia \\ ${ }^{4}$ Office of the Vice Chancellor, Universiti Putra Malaysia, 43400 UPM Serdang, Selangor, Malaysia
}

\begin{abstract}
This article highlights the University's strategic plan and institutionalization commitment in cultivating the green campus culture encircling the Green@UPM initiative. It presents a range of insights, lesson learned and way forward of UPM green strategies in continuously nurtures the environmentalfriendly campus atmosphere.
\end{abstract}

\section{Introduction}

A dynamic sustainability process in university require a holistic approach on university's teaching, research, operations and daily campus life. Campus community; individually and collectively roles in various environmental efforts are vital in engaging with the university's green systematic transformation fundamental. A comprehensive green campus mission aimed at achieving sustainability will indirectly create a new generation of socially and ecologically responsible citizens. In its role as a higher learning institution at the forefront of the sustainability movement, UPM is fully committed to alleviate and mitigate adverse environmental impacts. UPM is committed to provide services and to be developed based on the principles of sustainable development and responsible in raising the quality of life and ensure continuity of universal life (Fig. 1). In terms of campus environment, Sustainable Development Goals (SDGs) defines as fundamental that explains the importance of conserving ecological balance by reducing the depletion of natural resources. Comprehensively, SDGs adaptation into university management and operation, maneuver as the fundamental approach to addresses, involves and promotes, on the minimization of negative environmental, economic, societal, and health effects. It nourishes the transition of sustainable lifestyle of the campus society through the activities of teaching, research, outreach and partnership.

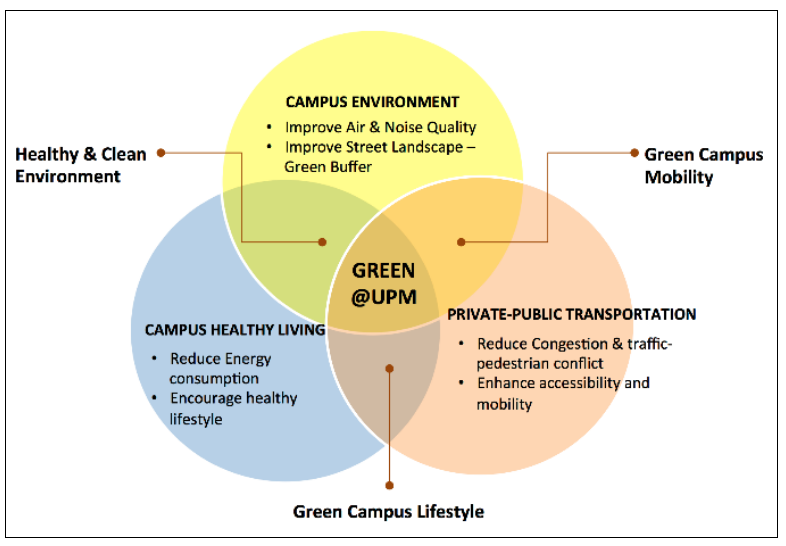

Fig.1. Green@UPM fundamental goals.

The Green@UPM strategic plan to meeting SDGs is outlined to reflect on university contributions on achieving the sustainable campus environment. Innovative projects aligned with the fundamentals and guidelines of sustainability and in connection with the SDGs are comprehensively planned to build campuswide green campus culture to addressing the issues arising from the imperative for university development, management and operation. Contribution of Green@UPM strategic plan to meeting SDGs is presented in Table 1 that evidently maximizes the survival and expansion of pioneering initiatives.

*Corresponding author: zaharin@upm.edu.my 
Table 1. Contribution of Green@UPM strategic plan to meeting SDGs.

\begin{tabular}{|c|c|}
\hline Sustainable Development Goals (SDGs) & Contribution of Green@UPM Strategic Plan to Meeting SDGs \\
\hline Goal 1. End poverty in all its forms everywhere & $\begin{array}{l}\text {-Centre For Management of Waqf, Zakat and Endowment (WAZAN) } \\
\text {-MySadaqah'TM@WAZANdiHati } \\
\text {-Sichuan Rural Poor- Household Biogas Programme of Activities" } \\
\text { (CDM PoA 2898, Gold Standard 1239) } \\
\text {-PadiU Putra Technology }\end{array}$ \\
\hline $\begin{array}{l}\text { Goal } 2 \text {. End hunger, achieve food security and improved } \\
\text { nutrition and promote sustainable agriculture }\end{array}$ & $\begin{array}{l}\text {-e-Rakan Bakti Putra } \\
\text {-UPM Freemeals Program } \\
\text {-Sichuan Rural Poor- Household Biogas Programme of Activities" } \\
\text { (CDM PoA 2898, Gold Standard 1239) } \\
\text {-Institute of Agricultural and Food Policy Studies } \\
\text {-Institute of Plantation Studies (IKP) } \\
\text { - Halal Products Research Institute } \\
\text {-Institute of Tropical Agriculture and Food Security (ITAFoS) }\end{array}$ \\
\hline $\begin{array}{l}\text { Goal 3. Ensure healthy lives and promote well-being for } \\
\text { all at all ages }\end{array}$ & $\begin{array}{l}\text {-Campus Car-Free-Zone Program } \\
\text { - Greener than Green program } \\
\text {-Cleaner than Clean program } \\
\text {-Carbon Footprint Reduction program } \\
\text { - Family, Adolescent and Child Research Centre Of Excellence (FACE) } \\
\text {-MALAYSIAN RESEARCH INSTITUTE ON AGEING (MyAgeing) }\end{array}$ \\
\hline $\begin{array}{l}\text { Goal 4. Ensure inclusive and equitable quality education } \\
\text { and promote lifelong learning opportunities for all }\end{array}$ & $\begin{array}{l}\text {-UPM Green Wave Roadshow } \\
\text { - Accepts students from IPTA who are interested to undergo industrial } \\
\text { trainings, year-end projects (undergraduates) and research projects in } \\
\text { Marine Science Centre } \\
\text { - Serdang Spirit Program } \\
\text { - Professors expert in environmental field } \\
\text {-Putra Science Park } \\
\text { - Faculty of Environmental Studies }\end{array}$ \\
\hline $\begin{array}{l}\text { Goal 5. Achieve gender equality and empower all } \\
\text { women and girls }\end{array}$ & $\begin{array}{l}\text {-Sichuan Rural Poor- Household Biogas Programme of Activities" } \\
\text { (CDM PoA 2898, Gold Standard 1239) } \\
\text {-Women Bus Coach } \\
\text {-Putra Bakti Program } \\
\text {-Women Political Participation Research } \\
\text {-Cancer Education and Research Project (CaEd) }\end{array}$ \\
\hline $\begin{array}{l}\text { Goal 6. Ensure availability and sustainable management } \\
\text { of water and sanitation for all }\end{array}$ & $\begin{array}{l}\text {-Greener than Green program } \\
\text { - Cleaner than Clean program } \\
\text {-Carbon Footprint Reduction program } \\
\text { - Green landscape rainwater harvesting } \\
\text { - River of Life @ Serdang programme } \\
\text {-Environmental Forensics Research Center }\end{array}$ \\
\hline $\begin{array}{l}\text { Goal 7. Ensure access to affordable, reliable, sustainable } \\
\text { and modern energy for all }\end{array}$ & $\begin{array}{l}\text {-UPM Biofore Company } \\
\text {-Biocompost Pilot Plant } \\
\text {-Bioprocessing and Biomanufacturing Research Center } \\
\text {-Fermentation Technology and Bioreactor System } \\
\end{array}$ \\
\hline $\begin{array}{l}\text { Goal 8. Promote sustained, inclusive and sustainable } \\
\text { economic growth, full and productive employment and } \\
\text { decent work for all }\end{array}$ & $\begin{array}{l}\text { - Green Sustainability Steering Committee } \\
\text {-3R Urban Garden Concept } \\
\text {-PadiU Putra Technology }\end{array}$ \\
\hline $\begin{array}{l}\text { Goal 9. Build resilient infrastructure, promote inclusive } \\
\text { and sustainable industrialization and foster innovation }\end{array}$ & $\begin{array}{l}\text {-TN50 Dialogue Series: The Aspiration of Green Technology Prospects } \\
\text {-MyCOMS Electric Vehicle } \\
\text {-Institute of Bioscience }\end{array}$ \\
\hline Goal 10. Reduce inequality within and among countries & $\begin{array}{l}\text {-Rebrand all green activities at main campus and branch campus - } \\
\text { including making existing program improvements } \\
\text {-International Green Research Collaboration }\end{array}$ \\
\hline $\begin{array}{l}\text { Goal 11. Make cities and human settlements inclusive, } \\
\text { safe, resilient and sustainable }\end{array}$ & $\begin{array}{l}\text {-Recycle@U } \\
\text {-Redcube Coca Cola Recycle Center }\end{array}$ \\
\hline $\begin{array}{lllll}\text { Goal } 12 . & \text { Ensure } & \text { sustainable } & \text { consumption } & \text { and } \\
\text { production patterns }\end{array}$ & $\begin{array}{l}\text {-Putra Green Campus } \\
\text {-Green Car Parking } \\
\text { •MyCOMS Electric Vehicle } \\
\text {-PadiU Putra Technology } \\
\end{array}$ \\
\hline $\begin{array}{l}\text { Goal 13. Take urgent action to combat climate change } \\
\text { and its impacts }\end{array}$ & $\begin{array}{l}\text {-UPM Waste Bank } \\
\text {-Greener than Green program } \\
\text { - Cleaner than Clean program }\end{array}$ \\
\hline
\end{tabular}




\begin{tabular}{|c|c|}
\hline & - Carbon Footprint Reduction program \\
\hline $\begin{array}{l}\text { Goal 14. Conserve and sustainably use the oceans, seas } \\
\text { and marine resources for sustainable development }\end{array}$ & $\begin{array}{l}\text {-UPM Marine Science Center (COMAS) } \\
\text {-Produces authentic live feed stock (Nannochloropsis oculata, } \\
\text { Chaetoceros aureus, Spirulina spp, Chlorella vulgaris) to be used in } \\
\text { PSM and spawn of lobsters } \\
\text {-Held workshops regarding lobsters together with researchers from } \\
\text { Universiti Malaya, Queensland University of Technology, Australia, } \\
\text { Universiti Selangor, University of Fiji, Department of Fisheries and UPM }\end{array}$ \\
\hline $\begin{array}{l}\text { Goal 15. Protect, restore and promote sustainable use of } \\
\text { terrestrial ecosystems, sustainably manage forests, } \\
\text { combat desertification, and halt and reverse land } \\
\text { degradation and halt biodiversity loss }\end{array}$ & $\begin{array}{l}\text { - Maintain existing UPM Green Policy and make UI-GreenMetric policy } \\
\text { and indicators mapping } \\
\text { - Coordinate green activities and agricultural visibility integratively } \\
\text { strategically } \\
\text { - Sultan Idris Shah Forest Education Center (SISFEC) } \\
\text {-Institute of Tropical Forestry and Forest Products (INTROP) }\end{array}$ \\
\hline $\begin{array}{l}\text { Goal 16. Promote peaceful and inclusive societies for } \\
\text { sustainable development, provide access to justice for all } \\
\text { and build effective, accountable and inclusive } \\
\text { institutions at all levels }\end{array}$ & $\begin{array}{l}\text {-UPM Green Policy } \\
\text { - Green Sustainability Steering Committee } \\
\text { •3R Urban Garden Concept }\end{array}$ \\
\hline $\begin{array}{l}\text { Goal 17. Strengthen the means of implementation and } \\
\text { revitalize the Global Partnership for Sustainable } \\
\text { Development }\end{array}$ & $\begin{array}{l}\text {-Green@UPM website } \\
\text {-Green Mandate } \\
\text {-Nature Education Camp \& Tree Planting } \\
\text {-Sustainable Merit/Assessment of Excellence Evaluation } \\
\text { Administration }\end{array}$ \\
\hline
\end{tabular}

\section{Successful approaches of green initiatives, commitment and way forward}

\subsection{The green campus management and policy}

Environmental management systems assist UPM in identifying and controlling the environmental impact of its activities and products, and in improving its environmental performance on an ongoing basis. Almost all of UPM's production sites, as well as wood-sourcing and forestry operations, have a verified environmental management system in place. UPM's aim is that all of its production units will have an environmental management system certification, including possible new units and acquisitions. The Green Mandate is an initiative of UPM to contribute towards environmental awareness in reducing carbon footprints among industries and create a more sustainable environment for our future. Echoing the spirit of 'Go Green, Reduce Carbon Footprints, Business Sustainability', UPM is promoting an environmental-friendly office atmosphere among industries in Malaysia. It is an effort to convey a strong message of awareness of the Green Nation to industries in Malaysia. In 2013, UPM has invited approximately 110 industries to join the The Green Mandate by registering their mandate [2]. It became the evidence of the industries' efforts in reducing the carbon footprint. Through participating the Green Mandate, the company will be classified as a Green initiative company. The Green Mandate 2013 shows that the industries in Malaysia are indeed concerned on the Green issues [2]. UPM has made significant improvements, particularly in the sectors of transport and infrastructure such as the size of available green space, in addition to the use of efficient energy-saving facilities and bicycles within the campus area.

\subsection{The green governance and campus community}

The university green governance is important to determine the direction of a green sustainability policy. UPM green governance is led by the vice chancellor of the university and supported by the green sustainability committees structured (Fig. 2).

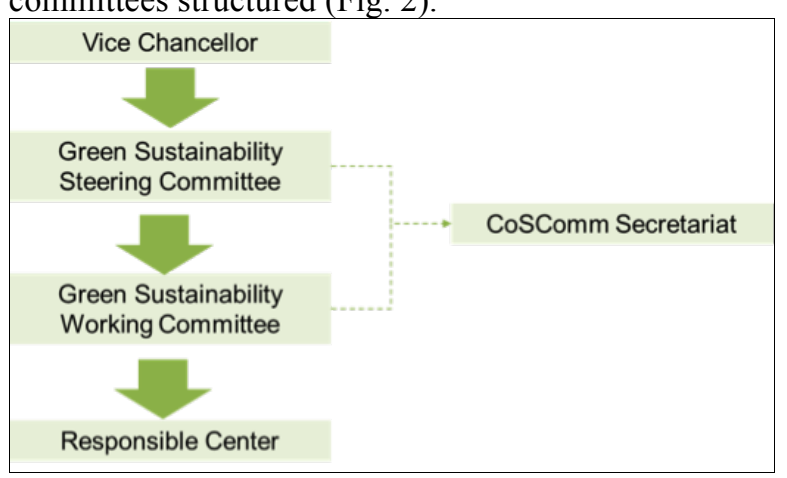

Fig. 2. UPM green governance structure.

The Green Sustainability Committee is responsible in formulating, planning and implementing all the activities/programs/projects according to UPM's Green Policy. Besides, the committee also reflects the commitment of UPM in forming network with various agencies to get funding or collaboration on green projects. It also ensures the continuous improvement and success of the green strategies implementation that requires a high competency in listening, communication, relationship building, vision development, responsiveness and continuous strategic adaptation from the university citizens. Right management framework will encourage more effective subcultures of decisionmaking style that promotes the top management-staffstudent-community and industries partnership. The widescale participation effectively increases the impact in illustrating the university commitment to environmental 
sustainable responsibility on regional and global level. This includes on direction to achieve the inclusiveness of SDGs main vision and aim towards shared large-scale participations on the program. The key characteristics of students, faculties' member and top management engagement that ensure the liveable and continuity of university are important.

\subsection{The leading green campus initiatives}

UPM has become a green sustainability leader among Malaysian institutions, as well as model that cultivate green activities in the teaching, learning, research and professional services ecosystem. The Green@UPM initiatives are our commitment to achieve environmental sustainability through strategic partnership with industries and the community as well as for higher campus quality of life. UPM Green Policy adopts five major pillars namely 1) to provide awareness and education, 2) to preserve biological diversity, 3) endeavor to reduce the release of greenhouse gases, 4) to reduce in way of waste management and motor vehicle dependency and 5) adopting the concept of sustainable development in the management and planning in the whole university's system (Fig. 3).

Additionally, this commitment has been translated into UPM's Green Sustainability Roadmap that is in line with Eleventh Malaysia Plan (RMKe-11) - "Pursuing green growth for sustainability and resilience" - 4 Focus Area (Fig. 4). The focus of Green@UPM direction is towards 1) strengthening the enabling environment for green growth, 2) strengthening resilience against climate change and natural disasters, 3 ) adopting the sustainable consumption and production concept; and 4) conserving natural resources for present and future generations.

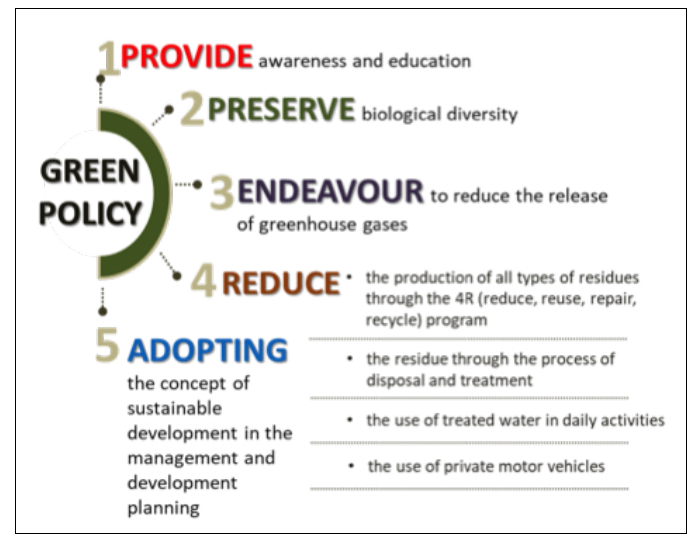

Fig. 3. UPM green policy [1].

Green@UPM way forward is focusing on five (5) strategic plans in engaging the campus community to involve with designated UPM green activities (Fig. 5). To heighten the UPM green profile, improvements to existing programs are made through action plan to rebrand all the green activities within the campus. Our strategic plan is also focus on maintaining the existing UPM green policy and mapping the policy with UIGreenMetric indicators. The university also looks forward in disseminating the information of green activities through websites and other media in reaching the community. Moreover, the future undertaking of green commitment is strategically coordinated to enhance the green activities and agriculture visibility

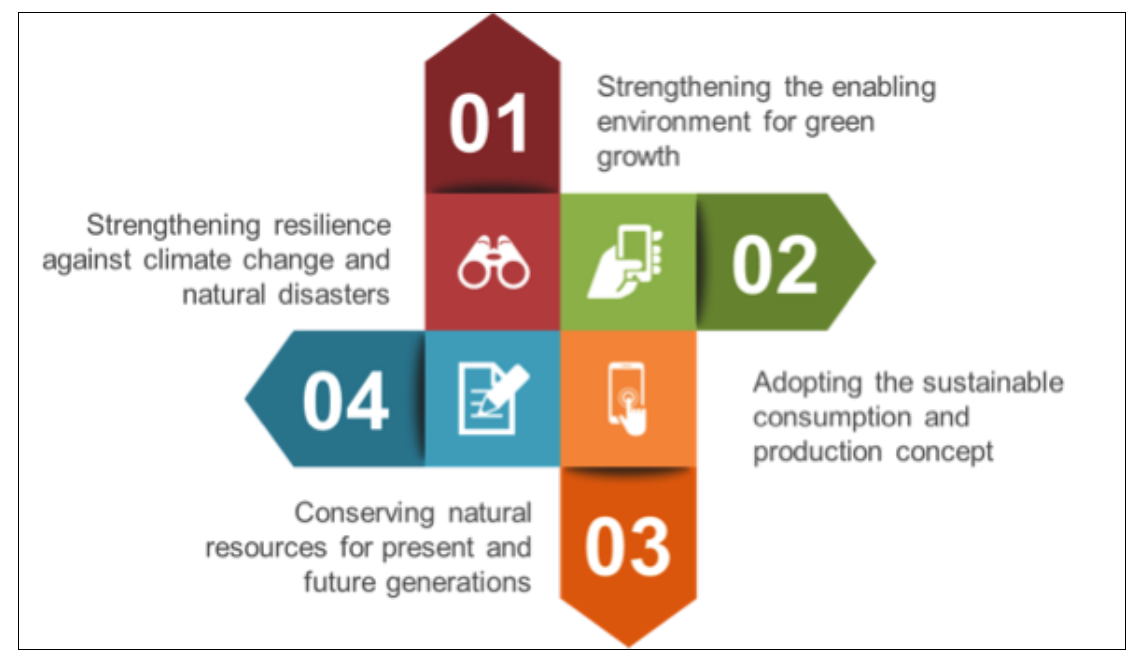

Fig. 4. UPM green sustainability roadmap. 


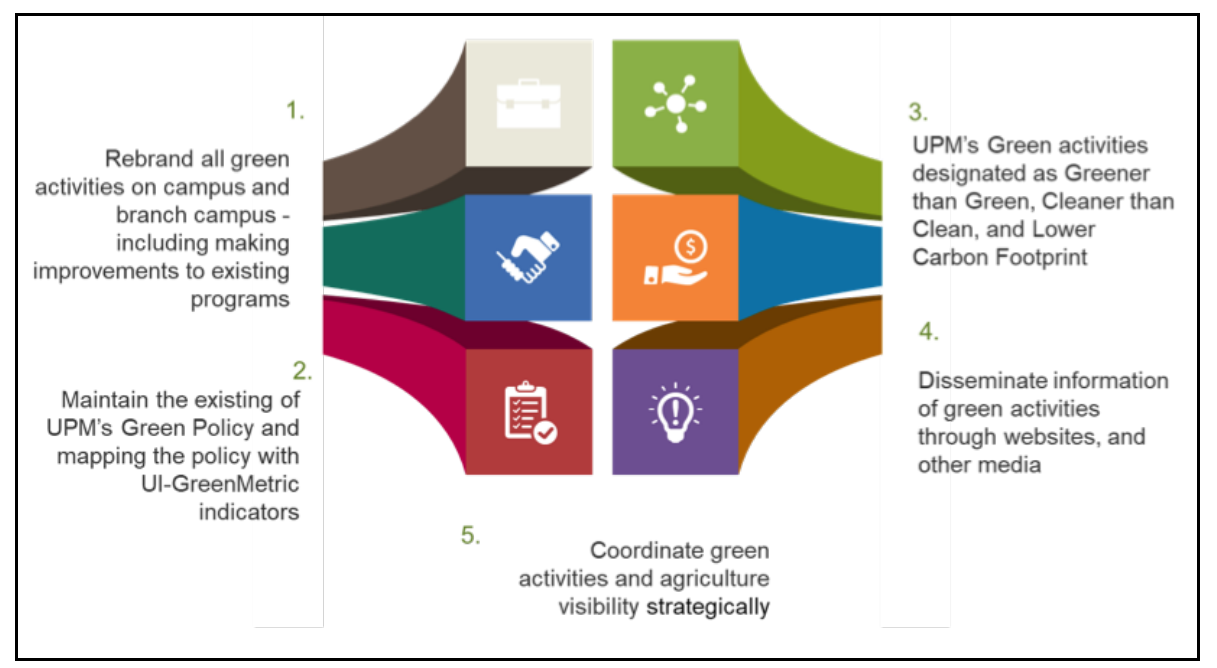

Fig. 5. UPM green strategy [1].

\section{Conclusion}

UPM is committed to conserve the environment through various eco-friendly and effective learning activities, research, co-curriculum and quality management systems based on sustainable and efficient environmental management. Starting with the inception of Green Policy in 2011, UPM has shown its green leadership capability which is reflected by the world recognition award, GreenMetric World University Ranking.

\section{References}

1. Green@ Universiti Putra Malaysia, Available online at http://www.green.upm.edu.my/, accessed on $2^{\text {nd }}$ of February 2018 (2016)

2. UPM Biofore Company, Available online at http://www.upm.com/, accessed on $2^{\text {nd }}$ of February 2018 (2016) 